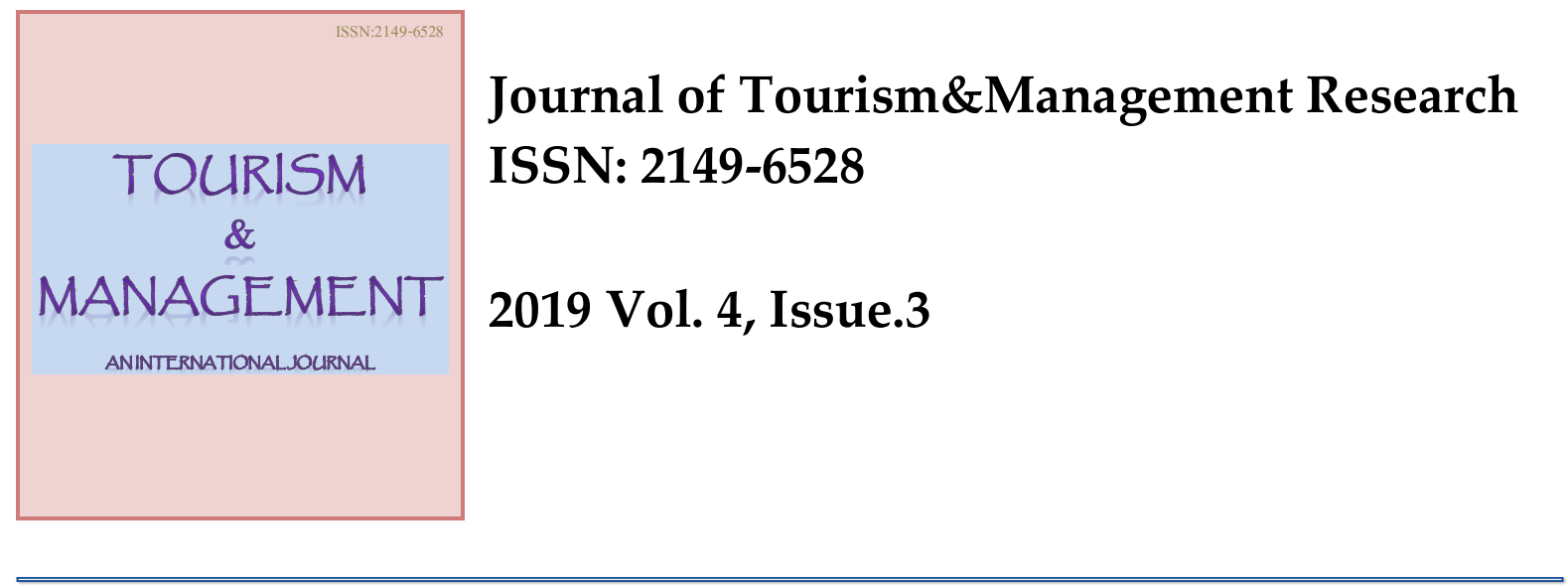

\title{
The Mediating Role of Employee Motivation on Internal Marketing and Employee Retention
}

\begin{abstract}
This study seeks to fill a gap by demonstrating how five Internal Marketing dimensions, namely, staff development, teamwork, internal communication, employee empowerment, and incentives and rewards effect on the retention of highly skilled employees. The concept of motivation sheds light on the relationship between internal marketing and employee retention. This study examines the mediating role of employee motivation in the relationship between employee retention in an international chain hotel company in Lebanon. The data were collected from 284 international chain hotel employees. The results of the study revealed that motivation, which is also positively related to employee retention, mediates the relationship between internal marketing and employee retention. Study results were consistent with the literature concerning the positive correlation between employee motivation and retention. During this survey, it noticed that the international chain hotel in Lebanon is currently in the process of implementing employee motivation. The results of the study corroborate that motivation is an important variable that positively impacts the relationship between internal marketing and employee retention.
\end{abstract}

Keywords: internal marketing, employee motivation, employee retention, hospitality industry, Lebanon.

JEL Classifications: M10, M31, O14, M15

Submitted:30/07/2019; Accepted:25/10/2019

Romeo Abu Melhem, PhD Student. Institute of Graduate Studies and Research, Department of Business Administration, Cyprus International University, North Cyprus

Email: romeo_abm@hotmail.com

Hale Ozgit, Associate Professor. (Corresponding Author). School of Tourism and Hotel Management, Cyprus International University, 99258 Haspolat, North Cyprus, Mersin 10 Turkey.

Email: hozgit@ciu.edu.tr 


\section{Introduction}

The service industry has become an essential part of virtually every nation's economy (Reid \& Bojanic, 2010) and a defining trait of today's digital economy. Thus, services providing sectors such as hospitality, banking, insurance, transportation, and media have become more competitive and allowed individual companies to dominate the market. As Tag-Eldeen \& ElSaid (2011) mentioned, talented and highly skilled employees play a substantial role in the service industry, particularly in the highly competitive hotel sector, where there is generally more interaction between customers and employees. Therefore, adopting effective employee retention strategies is essential for the success of service-based companies (Ahmed \& Rafiq, 2003).

One strategy is Internal Marketing (IM), an organizational policy that promotes the company's objectives, services and products to employees and significantly contributes to employee retention (Ahmed \& Rafiq, 2003). Thus, various studies have investigated the relationship between employee retention (ER) and IM (Ahmad \& Sheeraz, 2012; Omar \& Shehada, 2015). Scholars also noted that the positive effects of IM dimensions on the retention of employees help to build successful organizations. Five major IM dimensions, (a) staff development (SD) (Braimah, 2016), (b) internal communication system (IC) (Ahmad \& Sheeraz, 2012), (c) teamwork (TW) (Waddah \& Noorain 2015), (d) employee empowerment (EMP) (Omar \& Shehada, 2015), (e) programs of incentives and rewards (IR) (Narteh \& Odoom, 2015), have been singled out in previous studies to increase employee motivation (EM) and thus developing organizational performance.

Extended and considerable literature on IM seen in many studies (e.g., Berry, 1981; Berry \& Parasuraman, 1992; Grönroos 1981; Grönroos,1985; Piercy \& Morgan, 1991; Gummesson, 1987; Mudie, 1987). However, there are many discussions regarding the IM concept where, for three decades, forty-two definitions have proposed for this construct (Huang \& RundleThiele, 2014). Heretofore, IM literature lacks a standardized framework to investigate the mediating role of employee motivation in the relationship between IM and employee retention (ER). According to authors knowledge in this field in Lebanon, there were no earlier studies which empirically determine the effect of employee motivation and its mediating role in the relationship between IM and ER in Lebanon's hotel sector. The study bases its theoretical framework on empirical research by Ahmad \& Rafiq (2003) and Omar \& Shehada (2015), who explore the relationship between IM and IR. It also emphasizes the role of employee motivation as a mediating variable in the relationship between IM and ER. Besides, this study seeks to provide new insights into the antecedents of ER by showing how the adoption of IM strategies contribute to employee retention and motivation in the Lebanese hospitality industry. Despite the steady growth of leisure and business travel worldwide, the hospitality industry struggles with employee retention. While current research examines the impact of employee turnover on organizational productivity and performance, few studies address the effects of employee retention in the hospitality industry in Lebanon where leisure and business travel generate significant revenues.

In order to demonstrate the points described above, this study investigates the relationship between internal marketing dimensions and ER in one hand, and the strategies hotels should adopt to increase the retention of highly skilled and talented employees in the Lebanese context on the other.

\section{Theoretical Background and Hypotheses}

\subsection{The Development of the Lebanese Hotel Sector}

Today, competition among hotels in the Lebanese market has become more robust due to the emergence of many chain hotels. This situation, due to the political instability in the country, drove some chains such as Starwood, Marriott, and Sofitel (Accor) to end their operations. 
Lebanon has more than 340 hotels with around 21,000 rooms, and this is considered a significant number compared to surrounding countries. Add that from 2010 until today, more than 60 hotels applications for license acquisition presented to the Ministry of Tourism (Lebanon Ministry of Tourism, 2019). Many international chains exist and will be opened soon in Lebanon, and expected that room numbers would be increased by 2000 in 2019 . Lebanon had its door opened for globalization before the Lebanese war in 1977 in all fields. The hospitality field was also part of the globalization in Lebanon. Before the outbreak of war in the mid-1970s, Beirut had the best-developed hotel market in the Middle East.

\subsection{Theoretical Background}

The importance of IM lies in motivating the employees and encouraging them to offer super services to customers that will improve the customers' satisfaction regarding the services of the companies (Kukreja, 2017). IM was first described by Berry (1981), as a process in which the employee functions as an "internal customer" who performs a job which he characterizes as "a product." The notion of the employee as an internal customer was an efficient means to promote employee satisfaction, and to better equip them to provide quality products and services to external customers (Berry, 1981). Following this, Grönross (1981), defined IM as a management philosophy and a strategic marketing tool which is described as a "process of 'selling,' i.e., promoting the objectives of a corporation to its employees whom he also called 'internal customers'. IM also utilized as a vital marketing tool and motivation technique which supports organizational goals and objectives (Berry \& Parasuraman, 1992; Grönross, 1985).

Furthermore, Miles and Mangold (2004), found that IM can be a tool used in human resource management (HRM) to attract and retain employees. Recently, number of researchers demonstrated that, if IM if implemented, than it can positively impact service organizations by improving job satisfaction (Al-Hawary et. al., 2013), loyalty (Narteh \& Odoom, 2011), commitment (Braimah, 2016), and employee retention (Ahmad \& Sheeraz, 2012; Omar \& Shehada, 2015). According to Lings and Greenley (2010), IM implies a perspective centered around human resources management, based on the conceptualization of individuals' work as the main component of a firms' final products. Kameswari and Rajyalakshmi (2019) supported that internal marketing dimensions like training and skill development activities, work environment, superior support, coworker support and recognition have a significant impact on the satisfaction level of employees.

Although the literature on IM lacks a standardized framework to implement strategies, it offers a variety of elements which organizations can use to influence and motivate their employees. As mentioned earlier, this study draws the conceptual framework of IM developed by (Ahmad \& Sheeraz, 2012). Subsequently, Omar and Shehada (2015), further elaborated on Ahmad's conceptual framework to analyze the impact of IM on ER at private hospitals in Amman, Jordan. They noted that these hospitals implemented IM dimensions such as focusing on service culture, using a marketing approach to HR and marketing communication with employees, in addition to offering them incentives and rewards. Since scholars differ in their description and analysis of IM dimensions, there is no standard definition of the concept (Ahmed \& Rafiq, 2003). As a result, this study draws on. It investigates the following IM dimensions: internal communication, staff development, reward and recognition system, employee empowerment, teamwork, and the mediating role of employee motivation. This study operationalized the constructs of internal marketing mainly; internal communication, staff development, teamwork, empowerment and incentive rewards. These constructs discussed below.

\subsection{Staff Development and Employee Motivation}


Employees are an organization's greatest asset (Ahmed \& Rafiq, 2003). Therefore, the service sector should invest in training and developing their workforce to keep them up-to-date with the latest innovations and well-equipped to deliver quality services in a highly-competitive environment (Hammond \& Churchill, 2018; Jaworski et. al., 2018). Martensen and Grønholdt (2006), mentioned that employees who have undergone proper training, developed new skills and acquired knowledge are visibly more competent, secure and confident than their counterparts who have received inadequate training. Literature reveals that SD is an IM training strategy that leads to a systematic development of knowledge, skills and attitudes which employees should have in order to perform adequately (Abu ELSamen \& Alshurideh ,2012; Ahmad \& Sheeraz, 2012; Al-Hawary et. al., 2013; Back et. al., 2011; Braimah, 2016; Waddah \& Noorain, 2015; Narteh \& Odoom, 2011). Kaliyamoorthy (2018) found out that $\mathrm{SD}$ is one of the significant motivational factors to retention. It is also apparent that there is a positive relationship between staff development and employee motivation (Dar et. al., 2014). Nevertheless, SD helps to develop the overall personality of employees by making them more productive through developing a sense of TW. Training also boosts up the morale of the workforce, which is the most crucial factor in getting high profits. Employees get motivated through training as they gain clarity about their roles and boundaries as well as the expectations from them; they get a better knowledge of how to act in various situation or circumstances. Lukasik (2017), in his study, examined the effectiveness of on-the- job training conducted in the chosen group of companies to determine its impact on the motivation of employees. The results showed that companies should consider providing more useful training because, to a greater extent, they motivate employees, especially that $83 \%$ of them think that training improves their motivation. In this connection, the following hypothesis proposed:

Hypothesis 1: There is a positive relationship between staff development and employee motivation.

\subsection{Teamwork and Employee Motivation}

Various studies have indicated that when internal customers (employees) work as a team, they fully satisfy external customers. The term internal teamwork was characterised by Edmondson and Moingeon (1996, p.166) as "the extent to which team members engage in behaviours to monitor performance against goals, obtain new information, test assumptions and create new possibilities". Another study conducted by Drake et al. (2005) shows that the effective implementation of internal marketing can lead to better TW. Moreover, TW plays an especially important role as an IM dimension (Braimah, 2016; George \& Bennett, 2005; Waddah \& Noorain, 2015).

TW regarded as the key to staff development and businesses would benefit from successfully motivating people working in teams. According to Mumby (2013), the team will possess an aim and motivation to reach company goals and becomes a more comprehensive team. Based on their findings and the other studies described above, the following hypothesis will be tested.

Hypothesis 2. There is a positive relationship between teamwork and employee motivation.

\subsection{Internal Communication and Employee Motivation}

IC has been described as an essential IM tool in the literature (e.g., Braimah, 2016; Omar \& Shehada, 2015; Waddah \& Noorain, 2015). Moreover utilising internal communication is a prerequisite for the proper functioning of an organisation's internal activities (Al-Hawary et. al., 2013). Ineffective communications may lead to misunderstandings, lack of information, 
lower performance and more employee rotation. According to Pinder (2008), assigning more obligation and responsibility to employees, expressing recognition as well as having effective communication could also motivate employees. To succeed in intrinsic motivation, and affective IC system is required (Cheney et al., 2011). Managers are responsible for the given basis and generating intrinsic motivation from the company's side (Mishra et al., 2014). The following hypothesis, based on literature findings, will be tested in this study.

\section{Hypothesis 3: There is a positive relationship between internal communication and employee} motivation.

\subsection{Empowerment and Employee Motivation}

Employee EMP plays a vital role in the service sector (e.g., Ahmed \& Rafiq, 2003; AlHawary et. al., 2013; Berry \& Parasuraman, 1992; George \& Bennett, 2005; Grönross, 1981; Narteh \& Odoom, 2011). Wilson et. al. (2008) stated that many organisations understand that to be responsive to clients, employees should be empowered so that they can accommodate customer requests and act appropriately to solve unexpected problems. As an IM dimension, EMP is a process of authorising and enabling employees to act, behave, think and make decisions to fully perform their tasks (Al-Hawary et. al., 2013). Drake (2007) stated that motivated employees play a crucial role in organisational success. In addition to this, past research has indicated a positive association between perceptions of empowerment and motivation. Thus highly motivated employees are a critical factor in the long-term success of many organisations. As the results of these studies' findings indicate that IM dimensions are significantly associated with employee motivation, the following hypothesis will be tested.

Hypothesis 4: There is a positive relationship between empowerment and employee motivation.

\subsection{Incentives, Rewards and Employee Motivation}

The implementation of a fair reward and recognition system is another fundamental dimension of IM. Several researchers have investigated this dimension over the years. Studies on reward and recognition systems were conducted by different researchers (e.g., Ahmad, Zhou Maochun \& Rehman, 2019; Ahmed \& Rafiq, 2003; AL-Belushi \& Khan, 2017; Foreman \& Money, 1995; Narteh \& Odoom, 2011; Novianty \& Evida, 2018; Omar \& Shehada, 2015). Rewarding and recognition structure has a great impact on employee behaviour and organisational effectiveness (Freedman \& Montanari, 1980; Huseman \& Hatfield, 1990). As an effort to stimulate employees' creativity, many managers have used extrinsic rewards (e.g. monetary incentives) to motivate their employees (Fairbank \& William, 2001). Safiullah (2014), on the other side, found out that, with the advancement in the career path, income level and age, intrinsic rewards become the vital factor for employee motivation. Duly the following hypothesis will be tested.

Hypothesis 5: There is a positive relationship between incentives and rewards and employee motivation.

\subsection{Employee Motivation and Employee Retention}

Motivation defined as "willingness to reach high levels of effort toward organisational goals, conditioned by the effort's ability to satisfy some individual need" (Robbins, 1993). According to Mitchell (1982, p.2), motivation is "the sum of those psychological processes which are goal-oriented and caused by volunteer actions". Different studies have focused on employee motivation and its effects on ER (e.g., Ramlall, 2004; Samuel and Chipunza, 2009; 
Sandhya and Kumar, 2011). These studies have used the two-factor motivational theory by Herzberg (1957) to evaluate the effect of employee motivation on ER. According to Herzberg, employee motivation is a result of internal organisational values rather than external values. In other words, for his motivation is internal and is, therefore, affected by many variables which are intrinsic to what Herzberg called "employee motivators," i.e., the type of work an employee performs (Hezberg, 1957).

Retention was defined by Chaminade (2007) as an organisation's voluntary initiative to create a work environment that keeps employees engaged for the long term. Chiboiwa et. al. (2010, p. 2104) described ER as a strategy "to prevent the loss of competent employees from leaving productivity and profitability". Chew and Chan (2008), in their study, indicated that the hiring process had led organisations to pay special attention to the relevance of ER.

Moreover, to sustain a competitive advantage, organisations should maintain a stable workforce (Luna-Arocas \& Camps, 2008). The authors also indicated that employee retention is crucial to the overall success of organisations and is one of the most critical issues managers face, mainly due to a shortage of skilled human resources, limited economic growth, and high employee turnover. According to Kyndt, et. al. (2009), retaining talented employees as an asset is crucial because knowledgeable and skilful employees are central to a company's ability to gain competitive advantage. Besides, ER has become increasingly relevant to organisations because periodic labour shortages can reduce the availability of high performing employees (Jones \& Skarlicki, 2003, p. 1227). As a result, while workers are searching for better employment opportunities, firms are seeking to improve the productivity of their workforce (Leeves, 2000).

Nowadays, organisations are aware of the benefits of retaining employees, mainly because an employee intent to resign is often frustrating for both employees and employers. According to Lockwood and Ansari (1999), because organisations have to bear the costs of hiring and losing their employees, they should keep turnover low by retaining their staff. In fact, by retaining employees and valuing their skills, organisations preserve their investment in employee training, thus lowering the loss of human capital and increasing retention (Acton \& Golden, 2003).

It has also noted that employee turnover can also be affected by different factors such as the internal structure of the organisation, recruitment policies and strategies, career progression opportunities, rewards and benefits, and training and development (Fitz-enz, 1990). Moreover, improving employee-employer relations and employee commitment has proved to reduce turnover. Thus, organisational management policies should address the aspects as mentioned above of IM (Ahmad \& Sheeraz, 2012; Braimah, 2016; Narteh \& Odoom, 2015; Omar \& Shehada, 2015).

Motivation is an essential element which enhances the retention of the employee (Ahmad \& Sheeraz, 2012). Kaliyamoorthy et al. (2018) pointed out that there is a significant relationship between motivation and employee retention and work satisfaction and employee retention. Besides the study results by Sarmad (2016) revealed the impact of compensation and motivation on employees. The author also indicated that substantive enhancement in motivation level and practical handling of compensation might yield a corresponding improvement in employee retention. In a similar development, Aguenza \& Som (2012) investigated the motivational factors that influence employee retention. It recommended that organizations should holistically formulate appropriate retention strategies to reduce turnover rates, and this require employee motivation factors. Thus this leads to the following hypothesis.

Hypothesis 6: There is a positive relationship between employee motivation and employee retention. 


\subsection{Mediating Role of Employee Motivation on Internal Marketing and Employee Retention}

Dar et al. (2014) found that employee motivation is one of the most critical factors that can mediate the relationship between post-selection HRM practices and organizational performance. Furthermore, and according to their study, employee motivation mediates the relationship between SD, IR and the employee intention to stay, which could be used to back up the findings of this paper. Motivation has been regarded as one of the fundamentals to improve employee retention (Ramlall, 2004; Samuel \& Chipunza, 2009; Sandhya \& Kumar, 2011), and it is the primary tool of IM (Ahmed \& Rafiq, 2003; Locke \& Latham, 1990).

Moreover, a clear connection between motivation, employee responsibility and retention are well established in the literature (e.g., Ramlall, 2004; Samuel \& Chipunza, 2009; Sandhya \& Kumar, 2011; Zain \& Ghani, 2009). The following hypotheses were formulated based on the proposed research model.

Hypothesis7a: Employee motivation mediates the relationship between staff development and employee retention.

Hhypothesis7b: Employee motivation mediates the relationship between teamwork and employee retention.

Hypothesis7c: Employee motivation mediates the relationship between internal communication and employee retention.

Hypothesis7d: Employee motivation mediates the relationship between empowerment and employee retention.

Hypothesis7e: Employee motivation mediates the relationship between incentives and rewards and employee retention.

\subsection{Proposed Research Model}

According to the literature described in this study, researchers have asserted that five IM dimensions can be associated with employee retention. Moreover, motivation as a mediating variable positively affects the relationship between IM and ER. Figure 1 represents the framework of this research.

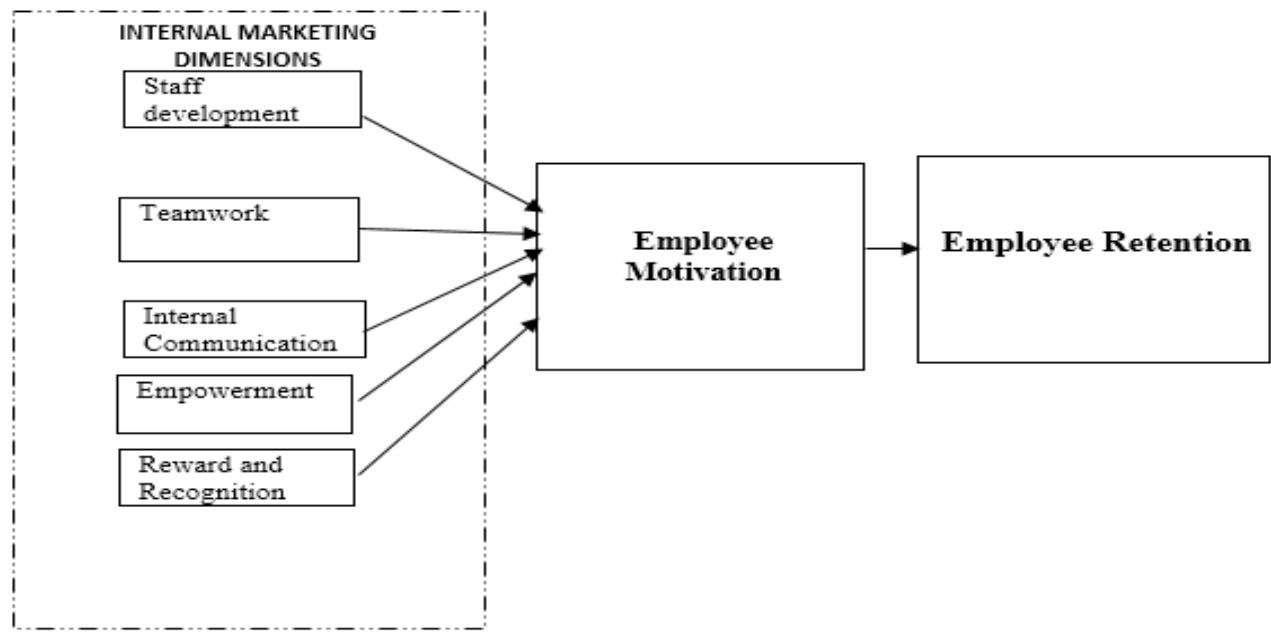

Figure 1. Research Model. 


\section{Methodology}

\subsection{Sampling and Data Collection}

The current study was conducted to determine the mediating role of motivation in the relationship between IM and ER. The sample of the study was driven from 1,330 international chain hotel employees working in Beirut, Lebanon the population of this study is referred to the Yamane's calculation method (Yamane, 1973) and confidence level is 95\%. The sample size of the study was calculated as $n=307$.

Stratified sampling was used to elect approximately equal numbers of employees for each chosen branch regarding each hotel's number of employee. Waddah and Noorain (2015) and Al-Hawary and Metabis (2012), have adopted the stratified random sampling technique due to its importance when there are many branches involved in the study. Five strata with stratified sampling technique used to allow the entire population. Each stratum represented one hotel, while the strata consisted of top management, middle-management, and employees. Also, the questionnaire was pilot tested with 29 employees from different branches of the chain hotel to find out whether it was necessary to revise its content. The pilot test showed that there was no reason to change the survey instrument. Of the 307 questionnaires, 284 completed and suitable for data analysis, the response rate was $92.5 \%$.

\subsection{Research Instrument}

The survey instruments were back-translated from English into Arabic by a certified translation service company. Responses to the items based on a 5-point scale option that varied from $1=$ strongly disagree, to $5=$ strongly agree. The survey instrument consisted of four sections. The five items used to measure motivation were adapted from Gounaris (2008), Al-Hawary et al. (2013), and Braimah (2016). Sample items include: (a) whether employees paid competitive salaries, (b) whether available fringe, benefits-and incentives offered, (c) whether employees were encouraged "to do their best" 30 IM dimensions adapted from Foreman \& Money (1995). To measure SD seven items, seven items for IC, seven items for EMP, and four items of TW, and five items related to the IM practice of IR adopted from Braimah (2016). Three control questions designed to describe the characteristics of the organisation and its employees, such as length of employment, job title and organisation size.

\subsection{Data Analysis}

The data were analyzed through The Statistical Package for Social Sciences (SPSS) version 23. In data, there were no missing values detected and observed that variables were not distributed normally. Descriptive statistics were used to identify the profile of the respondents and various independent variables. Statistical tests, such as independent sample t-test and ANOVA, were used to analyse differences between-group variance. Regression analysis was used to verify the relation between the dependent and the independent variable, while hierarchical regression was utilised to test the mediation effect of motivation on internal marketing and employee retention.

\section{Results}

\subsection{Descriptive Statistics}

Table 1 shows the number of participants in the survey, a total of 284 respondents from five branches of the chain hotel in Beirut. Among the respondents, 168 (59.2\%) were male, whereas $116(40.8 \%)$ were female. In addition to gender, the demographic profile of respondents shown in the table1, including age, position and years of employment. 
Table 1: Demographic Profile of Respondents.

\begin{tabular}{llll}
\hline Demographic variable & Category & No. of responses & Valid \% \\
\hline Gender & Female & 116 & 40.8 \\
& Male & 168 & 59.2 \\
\hline Job Position & Employee & 201 & 70.8 \\
& Supervisor & 64 & 22.5 \\
& Manager & 19 & 6.7 \\
& & & \\
\hline Age & 20 and below & 22 & 7.7 \\
& $21-24$ & 129 & 45.4 \\
& $25-40$ & 121 & 42.6 \\
& More than 41 & 12 & 4.2 \\
\hline Years of Employment & Less than a year & 59 & 20.8 \\
& 1-3 years & 101 & 35.6 \\
& 4-6 years & 86 & 30.3 \\
& More than 7years & 38 & 13.4 \\
\hline
\end{tabular}

\subsection{Exploratory Factor Analysis}

Cronbach's alpha coefficient test is used to test the internal construct reliability (Nunnally, 1978). The overall reliability for the scale exceeded the acceptable cut-off value of 0.70 Nunnally (1978). To perform exploratory factor analysis, and support the dimensionality and convergent validity, KMO and Bartlett's test of sphericity with varimax rotation was run. The construct exceeded the threshold value of $0.50(0.877>0.50)$ (Field, 2000). As a result, factor analysis could be used to simplify or reduce data. Table 2 shows the factor loadings for each variable. Factor loadings were greater than 0.50 , suggesting a satisfactory level of validity (Barclay, 1995).

\subsection{Scale Reliability}

Reliability test was undertaken to determine the internal consistency of the items that constituted each of the dimensions of internal marketing. For an item to retained in the scale, it should have a minimum factor loading threshold of 0.5 (Hair et. al., 2006), register an itemtotal-correlation greater than 0.3 (Blankson \& Stokes, 2002) while a factor must have a Cronbach Alpha score of at least 0.7 (Pallant, 2010). All the 39 items were retained after the reliability test (see table 2). All seven variables were also employed for further analyses as they all scored high Cronbach Alpha values, with .805 being the lowest score registered by staff motivation, and .937 is the highest Cronbach Alpha score. A scale reliability test was also conducted to assess the internal consistency of the overall scale. The global scale registered a high Cronbach's Alpha score of .967, meaning that the scale as a whole had a very high degree of internal consistency, and so was reliable (Nunnally, 1978).

Table 2: Means, standard deviations, factor loads and Cronbach's Alpha for all variables.

\begin{tabular}{|c|c|c|c|c|}
\hline Scale Items & Mean & SD & Factor loads & $\begin{array}{l}\text { Cronbach's } \\
\text { Alpha }\end{array}$ \\
\hline
\end{tabular}




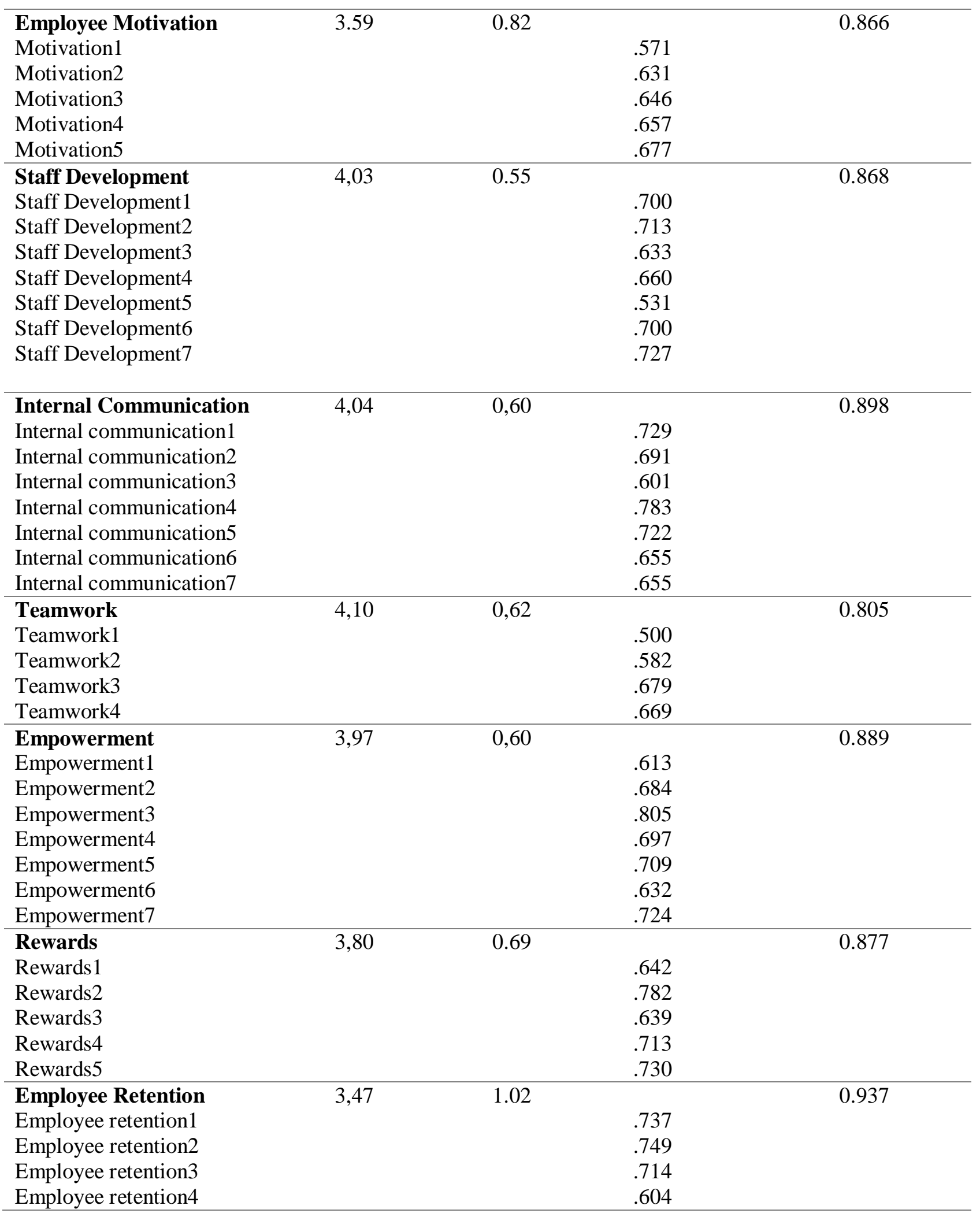

Notes: $N=284$. SD: standard deviation.

\subsection{Correlation Analysis Results}

Before testing the mediating role of the mediating variable in the relationship between predictors and outcomes, the correlation between independent and dependent variables and mediating variable were tested. The Pearson correlation statistical coefficient was used to verify the relationship between IM dimensions (SD, IC, T, EMP and IR), EM and motivation 
before doing hierarchical regression analysis. The correlation coefficient between all variables was positive. Pearson correlation coefficient indicates the significance, direction, strength and significance of the bivariate relationship among all the variables measured at an interval or ratio level (Sekaran \& Bougie, 2010). It is a statistical measure of association between two variables. The positive correlation coefficient $(r)$ ranges from \pm 0.41 to \pm 0.60 , while a strong correlation should be \pm 0.61 to \pm 0.80 . According to table 3 , there is a positive correlations between internal marketing dimensions such as SD $(r=0.618, p<0.01)$, TW $(r=0.534, p<$ $0.01), \mathrm{IC}$ is $(r=0.559, p<0.01)$, EMP $(r=0.593, p<0.01)$ and IR $(r=0.683, p<0.01)$ with employee motivation. Moreover ER $(r=0.717, p<0.01)$ was found to be positively correlated with employee motivation.

Table 3: Correlations between IM dimensions and Employee Motivation.

\begin{tabular}{|c|c|c|c|c|c|c|c|}
\hline Variables & SD & TW & IC & EMP & IR & ER & MOT \\
\hline Staff Development (SD) & 1 & & & & & & \\
\hline Teamwork (TW) & $.731^{* *}$ & 1 & & & & & \\
\hline Internal Communication (IC) & $.776^{* *}$ & $.634^{* *}$ & 1 & & & & \\
\hline Empowerment (EMP) & $.779^{* *}$ & $.637^{* *}$ & $.785^{* *}$ & 1 & & & \\
\hline Incentives \& Rewards (IR) & $.657^{* *}$ & $.586^{* *}$ & $.689^{* *}$ & $.741^{* *}$ & 1 & & \\
\hline Employee Retention (ER) & $.584^{* *}$ & $.465^{* *}$ & $.540^{* *}$ & $.586^{* *}$ & $.662^{* *}$ & 1 & \\
\hline Employee Motivation (EM) & $.618^{* *}$ & $.534^{\text {** }}$ & $.559^{* *}$ & $.593^{* *}$ & $.683^{* * *}$ & $.717^{* *}$ & 1 \\
\hline
\end{tabular}

\subsection{Hypotheses Testing}

Hierarchical regression was performed as shown in the tables 5-9 to estimate the effect of IM dimensions (SD, IC, T, EMP and IR) on ER and to examine whether EM mediates the relationship between IM dimensions and ER in the branches of the international chain hotel in Lebanon.

Table 5: Hierarchical regression for $\mathrm{H} 1$ and $\mathrm{H} 7 \mathrm{a}$.

\begin{tabular}{|c|c|c|c|c|c|}
\hline Hypothesized Relationships & $\begin{array}{c}\text { Regression } \\
\text { weights }\end{array}$ & $\begin{array}{c}\text { T- } \\
\text { values }\end{array}$ & Sig. & R Square & $\begin{array}{l}\text { Supported/Not } \\
\text { supported }\end{array}$ \\
\hline Step1. SD $\rightarrow$ ER & 0.584 & - & .000 & .341 & Supported \\
\hline $\begin{array}{c}\text { (I) Mediating effect of employee motivation } \\
\text { between SD and ER }\end{array}$ & - & & & & \\
\hline H7a SD $\rightarrow$ Employee Motivation $\rightarrow$ ER & 0.228 & 4.446 & .000 & .545 & Supported \\
\hline
\end{tabular}


Staff development is viewed to be one of the most crucial and pivotal factors related to employee retention in the hotel sector. Table 5 showed in both steps that staff development SD have a significant relationship with the dependent variable employee retention ER ( $\beta=$ 0.584 , Sig. 0.000). Thus H1 was accepted. The change in the value of the coefficient of SD ( $\beta$ $=0.584$, Sig. 0.000 to $\beta=0.228$, Sig. 0.000 ) suggests that EM mediates the relationship between SD and ER. The intervention caused by the mediating variable in the regression equation shown above proves that there is a strong relationship between SD and ER. Besides, the value of R-Square increased from 0.341 to 0.545 , thus demonstrating that EM plays a mediating role in the relationship between SD and ER. The p-value 0.000 is lower than the alpha-value 0.01. As a result, the descriptors used in this study's model are appropriate to identify the relationship between the predictor variables and the dependent variables. In line with this finding; hypothesis H7a was supported. Similarly to these results, another study showed that there is a significant linkage between training and ER (Gan \& Halimah, 2019; Hee \& Rhung, 2019; Kakar et. al., 2017). Kakar et al. (2017) mentioned that training could provide employees with updated skills and knowledge which will enhance ER.

Table 6: Hierarchical regression for $\mathrm{H} 2$ and $\mathrm{H} 7 \mathrm{~b}$.

\begin{tabular}{lcclll}
\hline Hypothesized Relationships & $\begin{array}{c}\text { Regression } \\
\text { weights }\end{array}$ & $\begin{array}{c}\text { T- } \\
\text { values }\end{array}$ & Sig. & R Square & $\begin{array}{l}\text { Supported/Not } \\
\text { supported }\end{array}$
\end{tabular}

\begin{tabular}{cccccc}
\hline Step1. TW $\rightarrow$ ER & 0.465 & - & .000 & .216 & Supported \\
\hline $\begin{array}{c}\text { (II) Mediating effect of employee motivation } \\
\text { between } \mathbf{T W} \text { and } \mathbf{E R}\end{array}$ & - & & & & \\
\hline H7b TW $\rightarrow$ Employee Motivation $\rightarrow$ ER & 0.115 & 2.356 & .019 & .523 & Supported \\
\hline
\end{tabular}

Findings regarding TW, as shown in table $6(\beta=.465$, Sig. $=.000$ to $\beta 3=-.115$, Sig .019) revealed that employee motivation positively impacts the relationship between TW and ER. Thus H2 was accepted. The value of R-Square increased from 0.216 to 0.523 which demonstrating that EM plays a mediating role in the relationship between TW and ER. The pvalue 0.019 is lower than the alpha-value 0.05 . As a result, the descriptors used in this study's model are appropriate to identify the relationship between the predictor variables and the dependent variables; thus hypothesis H7b was supported. This result is consistent with Hee \& Rhung (2019) who found that motivation and TW conditions, as well as comfortable workload and work environment, are all positively related to ER if adequate.

Table 7: Hierarchical regression for $\mathrm{H} 3$ and $\mathrm{H} 7 \mathrm{c}$.

\begin{tabular}{|c|c|c|c|c|}
\hline Hypothesized Relationships & $\begin{array}{c}\text { Regression } \\
\text { weights }\end{array}$ & $\begin{array}{c}\text { T- } \\
\text { values }\end{array}$ & R Square & $\begin{array}{l}\text { Supported/Not } \\
\text { supported }\end{array}$ \\
\hline
\end{tabular}

\begin{tabular}{lllllll}
\hline Step1. IC $\rightarrow$ ER & 0.540 & - & .000 & .291 & Supported \\
\hline $\begin{array}{l}\text { Mediating effect of employee } \\
\text { motivation between IC and ER }\end{array}$ & & & & & \\
\hline H7c IC $\rightarrow$ Employee Motivation $\rightarrow$ ER & 0.202 & 4.155 & .000 & .542 & Supported \\
\hline
\end{tabular}


The same results were shown in table 7 regarding IC which revealed a positive relationship with the dependent variable $\mathrm{ER}(\beta=.540$, Sig. $=.000$ to $\beta=.202$, Sig. 0.000). Thus H3 was accepted. The p-value 0.000 is lower than the alpha-value 0.01 and the value of R-Square increased from 0.291 to 0.542 , thus demonstrating that EM plays a mediating role in the relationship between IC and ER. H7c was supported as the results are consistent with the research of Titus and Adiza (2018) entitled "motivation: a panacea for employees' performance and retention" which showed that employee motivation had a significant relationship between effective internal communication and employee retention.

Table 8: Hierarchical regression for $\mathrm{H} 4$ and $\mathrm{H} 7 \mathrm{~d}$.

\begin{tabular}{lcclll}
\hline Hypothesized Relationships & $\begin{array}{c}\text { Regression } \\
\text { weights }\end{array}$ & $\begin{array}{c}\text { T- } \\
\text { values }\end{array}$ & Sig. & R Square & $\begin{array}{l}\text { Supported/Not } \\
\text { supported }\end{array}$
\end{tabular}

\begin{tabular}{lllllll}
\hline Step1. EMP $\rightarrow$ ER & 0.586 & - & .000 & .344 & Supported \\
\hline $\begin{array}{l}\text { Mediating effect of employee } \\
\text { motivation between EMP and ER }\end{array}$ & - & & & & \\
\hline H7d EMP $\rightarrow$ Employee Motivation $\rightarrow$ ER & 0.249 & 5.039 & .000 & .554 & Supported \\
\hline
\end{tabular}

Table 8 showed that EMP has a positive relationship with the dependent variable ER $(\beta=.586$, Sig. $=.000$ to $\beta=.249$, Sig. 0.000$)$. Thus $\mathrm{H} 4$ was accepted. The p-value 0.000 is lower than the alpha-value 0.01, and the value of R-Square increased from 0.344 to 0.554 , thus demonstrating that EM plays a mediating role in the relationship between EMP and ER. H7d was supported, and the results are similar to (Alhmoud and Rjoub, 2019; Hee and Rhung, 2019; Titus and Adiza, 2018) as they proved that empowerment conditions significantly related to motivation and employee retention.

Table 9: Hierarchical regression for $\mathrm{H} 5$ and $\mathrm{H} 7 \mathrm{e}$

\begin{tabular}{|c|c|c|c|c|c|}
\hline Hypothesized Relationships & $\begin{array}{l}\text { Regression } \\
\text { weights }\end{array}$ & $\begin{array}{c}\text { T- } \\
\text { values }\end{array}$ & Sig. & R Square & $\begin{array}{l}\text { Supported/Not } \\
\text { supported }\end{array}$ \\
\hline Step1. IR $\rightarrow$ ER & 0.662 & & .000 & .438 & Supported \\
\hline $\begin{array}{l}\text { (V) Mediating effect of employee motivation } \\
\text { between IR and ER }\end{array}$ & - & & & & \\
\hline H7e IR $\rightarrow$ Employee Motivation $\rightarrow$ ER & 0.323 & 6.022 & .000 & .569 & Supported \\
\hline
\end{tabular}

Moreover, table 9 shows that there is significant relationship between IR and ER $(\beta=.662$, Sig. $=.000$ to $\beta=.323$, Sig. 0.000 ). Thus H5 was accepted. The value of R-Square increased from 0.438 to 0.569 . In line with these findings, H7e was supported. Many researchers previously presented similar results (Alhmoud and Rjoub, 2019; Hee and Rhung, 2019; Titus and Adiza, 2018) as they proved that rewards significantly related to motivation and employee retention. 


\section{Conclusion, Implications and Limitations}

This study was an attempt to examine the critical impact of five IM dimensions: staff development, internal communication, teamwork, empowerment and incentives and rewards, on ER in an international chain hotel in Lebanon. Thus, employee motivation (EM) was considered a mediating variable.

As discussed previously, employee motivation affects the relationship between IM and ER positively. In addition to this, motivation is simultaneously a means to engage existing employees in SD programs and acquire a positive outcome of these programs. Thus, recent research has extensively examined the effect of staff development (SD) on ER by showing how it is intrinsically related to motivation.

Various scholars have demonstrated that organisations are increasingly more aware that their most valuable asset is their employees (e.g. Alhmoud \& Rjoub, 2019; Gan \& Halimah, 2019; Hee \& Rhung, 2019; Shah \& Asad, 2018; Titus \& Adiza, 2018). This trend is also noticeable in the hotel sector, where hiring highly qualified workers has become a priority. Moreover, management has begun to organise SD programs to improve the performance and skills of new and existing employees as a means to invest in the workforce and offer highquality service. Even though organisations are aware of the high cost of these programs, they understand that their investment in SD will be eventually recovered and guarantee future returns.

Different studies have also demonstrated that SD is one of the critical components of IM dimensions (e.g., Al-Hawary et. al., 2013; Braimah, 2016; Ismail \& Sheriff, 2015). Their findings are consistent with the results of the study by (Ahmad \& Sheeraz, 2012) on the effect of IM on ER. Moreover, Lukasik (2017) and Kaliyamoorthy et al. (2018) have proved that there is a positive relationship between SD and EM. Thus, the research as mentioned above supports this study's results. In addition to that, it has shown a positive correlation between $\mathrm{SD}$ and EM that have mediated the relationship between these two variables.

Another critical IM practice, internal communication (IC), is a process where employees in an organisation are encouraged to share information, ideas, opinions and plans with fellow employees or supervisors in writing or orally. Managers, on the other hand, use IC to inform employees of new policies and strategic objectives. Managers also utilise IC to provide employees with constructive feedback about their performance and to understand their needs. Thus, when managers effectively communicate with employees by listening to their requests and answering their questions, they open channels of excellent communication with their staff. As a result, both employee satisfaction and ER increase. Regarding the use of IC in the international chain hotel in Lebanon, this study's statistics suggest that IC is positively correlated with EM. This result also coincides with those of Pinder (2008) and Mishra et al., (2014) in which the IC corroborates a positive correlation between IC and EM.

Various studies have also shown that teamwork, as an IM variable, is positively correlated with EM. Researchers have argued that the engagement of employees in T positively affects the overall performance of the organisation. Moreover, $\mathrm{T}$ has been described as a substantial element in the relationship with EM (Jiang, 2010; Mumby, 2013). Similarly, this study maintains that when hotel management encourages a collaborative environment in its hotel, TW will be effective and will positively impact employee loyalty and ER.

EMP was a significant driver of ER in the hotels investigated in this study and is positively correlated with EM. This finding implies that management should encourage staff to use their discretion and take the initiative. In the hotel industry, this managerial approach can make employees feel relevant and improve their loyalty to the organisation. Other researchers have argued that when employees are free to handle customers, they develop a high sense of personal worth and, consequently, are more committed to the organisation. 
Moreover, this study singled out the particular role EMP plays in promoting EM in the international chain hotel. Thus, management should encourage staff to use their experience and skills to improve service quality. Doing so, this will allow employees to develop selfconfidence and increase their sense of responsibility. As Drake (2007) has shown, EMP improves staff dedication. Moreover, employee empowerment has been advocated by management and accounting researchers as a way to increase employee motivation.

As an IM dimension, EMP is a means to enable and encourage employees to act, behave, think and make decisions to get the job done (Al-Hawary et al., 2013). Andrea et al. (2007) stated that motivated employees play a crucial role in organisational success. These results have similarities with the current study, particularly regarding the positive correlation between EMP and EM, which positively affect employee loyalty and retention.

IR is positively correlated with EM, and its relevance is such that it is seen as the significant IM dimension in research by Kassa (2015) who declared in their study that employees are highly motivated with a rewards system. Beside, Safiullah (2014) mentioned that rewards become the vital factor for employee motivation. This study's findings are consistent with the research by Omar \& Shehada (2015) in which the researchers examine the impact of IM on ER at private hospitals in Amman, Jordan where IR implementation was measured as beta $(.348$, sig. at 0.003$)$, the strongest predictor of variation in the overall ER.

$\mathrm{EM}$, which is also positively related to ER, noticeably mediates the relationship between IM and ER. Based on this study's result, it is possible to infer that motivation is positively related to employee motivation in the international chain. Thus, motivating employees should be central to management. Managers should acknowledge that employees are the organisation's most valuable asset since they create tangible products and offer intangible services. For example, according to Hee \& Rhung (2019), giving the employees a sense of achievement and providing them with opportunities for career advancement and promotion constitutes a critical motivator that creates positive job attitudes. Moreover, investing in the workforce eventually generates returns to the organisation.

This study's results regarding EM are also consistent with Ahmad \& Sheeraz (2012), who demonstrated a positive correlation between EM and ER. Finally, during this survey, it was noticed that the international chain hotel in Lebanon is currently in the process of implementing motivation. Their initiative corroborates this study's contention that $\mathrm{M}$ is an important variable that positively impacts the relationship between IM and ER.

\subsection{Managerial Implications}

According to Tag-Eldeen \& El-Said (2011), IM dimensions are an essential element in an organisation. The results of this study show that IM has a significant positive relationship with ER. Therefore, when IM is effective, employee turnover is low, and retention is high. Moreover, the IM dimensions addressed in this research have been frequently adopted by various organizations to facilitate strategic management.

Regarding the IM dimensions of the international chain hotel in Lebanon, it is demonstrated that employees perceive the significance of the organization's IM dimensions such as SD, IC, T, EMP and IR before deciding whether they will continue working at the organization. Besides, it was found that there is a significant relationship between independent variables and the ER. Thus, it can be asserted that this study's findings are a reliable tool to identify the best strategies hotel management should implement to improve ER.

Moreover, our results indicate that several employees are dissatisfied with the hotel's IM practices. Consequently, hotel management should be aware of the significance of IM practices because, as it has been demonstrated, they have a substantial effect on retention. 
Therefore, management should periodically review their IM strategies and regularly implement them in order to reduce turnover. Holding staff meetings, promoting events, and encouraging the exchange of ideas is a means to design and set specific and reasonable goals that employees can attain. By motivating employees, the hotel can improve the organizational reputation and increase employee loyalty and efficiency. This research has highlighted the importance of EM in the relationship between IM and ER this makes the hotel's managers, especially in Lebanon, aware of the decisive role that employee motivation plays in the purpose of retaining valuable and talented employees.

\subsection{Limitations of the Study and Recommendations for Future Research}

The present study has several limitations. Firstly, it is limited to international chain hotels in Lebanon. However, this decision made because the hotel staff is mostly from Lebanon, a country characterized by high levels of unemployment, brain drain and seasonal hospitality industry. Besides, conducting this research was a challenge, since Lebanon's complex, volatile and fragmented business environment could be inadequate to implement ER.

This study was conducted to identify the impact of IM on ER with the mediating role of EM in the international chain hotel in Lebanon while assuming, based on previous research, that employees are an organization's main asset. This research has not established whether the chain hotels have addressed their employees' needs or their intention to leave or stay in their jobs.

In addition to study results, apart from the IM practices examined, other strategies may improve ER, which this study did not address, such as offering job stability and encouraging retention in weak labour markets. Thus, researchers should investigate volatile business environments in which turnover is high and is also a common organizational practice. Doing so will address whether ER can increase organizational performance despite an adverse business scenario.

Additionally, researchers can create new variables to test IM or apply the existing ones to different contexts. For example, as seen in the literature, there are relevant variables identified by various researchers such as job satisfaction (Al Hawary et al., 2013), service culture (Omar \& Shehada, 2015; Tag-Eldeen \& El-Said, 2011) and vision (Foreman \& Money, 1995). As mentioned earlier, due to time constraints and limited resources, this study's sample and instruments were not sufficient to collect more detailed information on ER. Thus, researchers should elaborate questionnaires that limit the respondents' tendency to provide unreliable information, a practice that is common in contexts where the job market restricted due to insecurity and other issues.

Future studies are thus encouraged to design a more complex project and research plan that allows them to target participants from different geographical locations in Lebanon and who employed in other hotels across the country. Researchers should also include in their studies employees in different service sectors such as insurance, banking, technology and communications, and compare their ER rates with those of the hospitality industry. In doing so, future studies will better evaluate the effects of employee turnover in these different sectors and propose new strategies to improve organizational performance by promoting ER.

\section{References}

Abu ELsamen, A., \& Alshurideh, M. (2012). The Impact of Internal Marketing on Internal Service Quality: A Case Study in a Jordanian Pharmaceutical Company. International Journal of Business and Management. 7(19), 84-95. 
Acton, T., \& Golden, W. (2003). Training the Knowledge Worker: A Descriptive Analysis of Training Practices in Irish Software Companies. Journal of European Industrial Training, 27(2/3/4), 137-146.

Aguenza,B.B., \& Som, A.P.M (2012). Motivational Factors of Employee Retention and Engagement in Organization.International. Journal of Advances in Management and Economics, 1(6), 88-95.

Ahmad, M, Zhou Maochun, Z., \& and Rehman, A. (2019). The Role of Financial Incentives in Employee's Job Motivation, Satisfaction, Performance, and Turnover: Evidence from Pakistan, Asian Basic and Applied Research Journal. 1(2), 3944.

Ahmad, N., Iqbal, N., \& Sheeraz, M. (2012). The effect of internal marketing on employee retention in Pakistani banks. International Journal of Academic Research in Business and Social Sciences, 8(2), 270-280.

Ahmed, P. K., \& Rafiq, M. (2003). Internal marketing issues and challenges. Journal of Marketing, 37, 1177-1186.

Al-Belushi, F.Y. and F.R. Khan, 2017. Impact of monetary incentives on employee's motivation: Shina's college of technology, Oman - a case study. International Journal of Management, Innovation \& Entrepreneurial Research, 3(1): 1-11.

Al-Hawary, S. I. S, Al-Qudah, K. A. M., Abutaieh, P. M., Abutaieh, S. M., \& Al-Ziadat, D. A. (2013). The impact of internal marketing on employee's job satisfaction of commercial banks in Jordan. Interdisciplinary Journal of Contemporary Research in Business, 9(4), 811-826.

Al-Hawary, S.I.S. \& Metabis, A. (2012) Implementation of Internal Marketing in Jordan Banks- International Journal of Data Analysis and Information, 4(1), 37-53.

Alhmoud, A., \& Rjoub, H. (2019). Total Rewards and Employee Retention in a Middle Eastern Context. SAGE Open, 9(2), 1-13.

Al-Makhadmah, I. M. (2015). The relationship between internal marketing practices and job satisfaction in four and five-star hotels in the Dead Sea, Jordan. European Journal of Business and Management, (7)35, 117-124.

Andrea, R.D., Jeffrey, W., \& Stephen, B.S.(2007) Empowerment, Motivation and Performance: Examining the Impact of Feedback and Incentives on Nonmanagement Employees. Behavioral Research in Accounting, 19(1), 71-89.

Anis, A., Rehman, I.U. \& Safwan, N. (2011) Employee retention relationship to training and development: A compensation perspective. African Journal of Business Management, 5(7), 2679.

Back, M.D., Schmukle, S.C., \& Egloff, B. (2011). A closer look at first sight: Social relations lens model analyses of personality and interpersonal attraction at zero acquaintance. European Journal of Personality, 25,225-238.

Barclay, D.W., Thompson, R., \& Higgins, C. (1995). The partial least squares (PLS) approach to causal modelling: Personal computer adoption and use an illustration. Technology Studies, (2)2, 285-309.

Berry, L. L. (1981). The employee as customer. Journal of Retail Banking, (3), 33-40.

Berry, L. L., \& Parasuraman, A. (1992). Service marketing starts from within. Marketing Management, (1), 24-34.

Blankson, C. \& Stokes, D. (2002). Marketing practices in the UK small business sector. Marketing Intelligence \& Planning, 20(1):49-61.

Braimah, M. (2016). Internal marketing and employee commitment in the hospitality industry. African Journal of Hospitality, Tourism and Leisure, (5), 2, 1-22.

Byju, K.P.M. (2013). Internal marketing: Employee does matter. Global Journal of Management and Business Studies, 3(5):519-524. 
Capelli, P. (1997). Change at work. New York, NY: Oxford University Press

Chaminade, B. (2006). A retention checklist: How do you rate? HR Leader Retrieved.

Cheney, G., Christensen, L. T., Zorn, T. E., \& Ganesh, S. (2011). Organizational communication in an age of globalization: Issues, reflections, practices. Prospect Heights, IL: Waveland Press.

Chi Y. I. \& Lam, D. (2016). Role of internal marketing on employees' perceived job performance in an Asian integrated resort. Journal of Hospitality Marketing Management, 5 (25), 589-612.

Chitrao, P. (2014). Internal communication satisfaction as an employee motivation tool in the retail sector in Pune. The European Journal of Social \& Behavioural Sciences, 10(3), 1541.

Clark, R. E. (2003) Fostering the work motivation of individuals and teams. Performance Improvement, 42(3), 21-29.

Dar, A. T., Bashir, M., Ghazanfar, F., \& Abrar, M. (2014). Mediating role of employee motivation in relationship to post-selection HRM practices and organizational performance. International Review of Management and Marketing, 4(3), 224-238.

Drake, A. R., Wong, J., \& Salter, S. B. (2007). Empowerment, motivation, and performance: Examining the impact of feedback and incentives on nonmanagement employees. Behavioural research in accounting, 19(1), 71-89.

Edmondson,A., \& Moingeon, B.(1996). When to learn how and when to learn why: Appropriate organizational learning processes as a source of competitive advantage. Thousand Oaks, CA, US: Sage Publications, Inc.

Fairbank, J. F., \& Williams, S. D. (2001). Motivating creativity and enhancing innovation through employee suggestion system technology. Creativity and innovation management, 10(2), 68-74.

Field, A. (2000). Discovering Statistics Using SPSS for Windows. London-Thousands OaksNew Delhi: Sage Publications.

Fitz-enz, J.(1990). Getting and keeping Good Employees. In Personnel. 67(8): 25-29.

Foreman, S.K. and Money, A.H., (1995). Internal marketing: concepts, measurement and application. Journal of Marketing Management, 11 (8), 755-768.

Freedman, S. M., \& Montanari, J. R. (1980). An integrative model of managerial reward allocation. Academy of Management Review, 5(3), 381-390.

Gan, J. L., \& Halimah, M.Y. (2019). The Relationship between Training and Employees' Retention: A Review Paper. International Journal of Entrepreneurship and Management Practices, 2 (5), 16-24.

George, A.L.,\& Bennett, A.(2005). Case studies and theory development in the social sciences. Cambridge, Mass: MIT Press.

George, R.W., (1990). Internal marketing and organizational behavior: A partnership in developing customer-conscious employees at every level. Journal of Business Research, 20(1), 63-70.

Görnroos, C. (2000). Service management and marketing: A customer relationship management approach. Hoboken, NJ: John Wiley \& Sons.

Gounaris, S. (2008). The notion of internal market orientation and employee job satisfaction: some preliminary evidence. Journal of Services Marketing, 22(1), 68-90.

Grönroos, C. (1981). Internal marketing-an integral part of marketing theory. Marketing of services, 236, 238.

Grönroos, C. (1985). Internal marketing theory and practice. Service marketing in a changing environment. In Bloch, T. M., Upah, G. D., \& Zeithaml, V. A. (Eds.). Chicago: American Marketing Association, pp. 41-47. 
Grönross, C. (1994). A service quality model and its marketing implications. European Journal of Marketing, (4), 36-44.

Gummesson, E. (1987). Using internal marketing to develop a new culture - the case of Ericsson quality. Journal of Business \& Industrial Marketing, 2(3), 23-28.

Hair Jr, J.F., Black, W.C., Babin, B.J., Anderson, R.E. \& Tatham, R.L. (2006). Multivariate data analysis. New Jersey: Pearson.

Hammond, H., \& Churchill, R. Q. (2018). The role of employee training and development in achieving organizational objectives: A study of Accra Technical University. Archives of Business Research, 6(2), 67-74.

Hee, O. C., \& Rhung, L. X. (2019). Motivation and Employee Retention among Millennials in Malaysia. International Journal of Academic Research in Business and Social Sciences, 9(2), 876-884.

Herzberg, F., Mausner, B., Peterson, R. O., \& Capwell, D. F. (1957). Job attitudes: Review of research and opinion. Pittsburgh, PA: Psychological Services of Pittsburgh.

Huang, Y.T. and Rundle-Thiele, S. (2014). The moderating effect of cultural congruence on the internal marketing practice and employee satisfaction relationship: An empirical examination of Australian and Taiwanese born tourism employees, Tourism Management, 42(1), 196-206.

Huseman, R. C., \& Hatfield, J. D. (1990). Equity theory and the managerial matrix. Training \& Development Journal, 44(4), 98-103.

Ismail, W., \& Sheriff, N.M. (2015) Validation of Measurement Model of Internal Marketing in Banking Sector in Yemen. International Academic Research Journal of Social Science, 1(2), 131-138.

Janet, C., \& Christopher, C.A. (2008). Human resource practices, organizational commitment and intention to stay. International Journal of Manpower, 29(6), 503-522.

Jaworski, C., Ravichandran, S., Karpinski, A. C., \& Singh, S. (2018). The effects of training satisfaction, employee benefits, and incentives on part-time employees' commitment. International Journal of Hospitality Management, 74, 1-12.

Jiang, X. (2010). How to motivate people working in teams? International Journal of Business and Management, 5(10), 223.

Jones, D., \& Skarlicki, D. (2003). The relationship between perceptions of fairness and voluntary turnover among retail employees. Journal of Applied Social Psychology, 6(33), 1226-1243.

Kakar, P., Raziq, A., \& Khan, F. (2017). Impact of Human Resource Management Practices on Employee Retention: A Case of Banking Sector in Quetta Baluchistan. Journal of Management Info, 4(3), 5-11.

Kaliyamoorthy, S., Hamoud Al- Shibami, A., Nusari, M., \& Ghosh, A. (2018). Effect of motivation on employee retention in Malaysians hotels. International Journal of Management and Human Science (IJMHS), 2(1), 37-42.

Kameswari, A., \& Rajyalakshmi, N. (2019). Role of Internal Marketing in Job Satisfaction of Employees in State Bank of India. 9th AIMS International Conference on Management, India.

Kapur, S. (2010). Call for rethink on staff retention strategies. Retrieved from https://www.emirates247.com/eb247/economy/regional-economy/call-frethink-onstaff-retention-strategies-2010-06-01-1.250259. Accessed on 5 May 2019.

Kassa T. (2015). Employee Motivation and its Effect on Employee Retention in Ambo Mineral Water Factory. International Journal of Advance Research in Computer Science and Management Studies, 3 (3), 10-21.

Kreitner, R., \& Kinicki, A. (1998). Organizational Behavior. Boston, MA: Irwin McGrawHill. 
Kukreja, J. (2017). Internal Marketing: a prelude or an outcome of Employee Motivation? BVIMSR's Journal of Management Research, 9(1), 54.

Kyndt, E., Dochy, F., Michielsen, M., \& Moeyaert, B. (2009). Employee retention: Organisational and personal perspectives. Vocations and Learning, 2(3), 195-215.

Leeves, G. (2000). Worker turnover: Hires, separations and employment growth at the employer Level. Australian Journal of Labour Economics, 4(4), 280-295.

Lings, I. N., \& Greenley, G. E. (2010). Internal market orientation and market-oriented behaviours. Journal of Service Management, 21(3), 321-343.

Lockwood, D. and Ansari, A. (1999). Recruiting and retaining scarce information technology talent: a focus group study. Industrial Management and Data Systems, 99(6), 251256.

Łukasik, K. (2017). The Impact of Training on Employees Motivation in SMEs Industry. Zeszyty Naukowe Politechniki Częstochowskiej. Zarzadzanie, (28, t. 1), 96-109.

Luna-Arocas, R., \& Camps, J.(2008). A model of high-performance work practices and turnover intentions. Personnel Review, 37(1), 24-26.

Martensen, A., \& Grønhldt, L. (2006). Internal Marketing: A study of Employee Loyalty, Its Determinants and Consequences. Innovative Marketing, 2(4), 92-116.

Maslow, A. H. (1943). A Theory of human motivation. Psychological Review (50), 394-395.

Mello, J. (2010). Strategic Human Resource Management. Stamford, CA: Cangage Learning.

Miles, S. J., \& Mangold, G. (2004). A conceptualization of the employee branding process. Journal of Relationship Marketing, 2-3 (3), 65-87.

Mishra, K., Boyton, L., \& Mishra, A. (2014). Driving Employee Engagement: The Expanded Role of Internal Communications. International Journal of Business Communication, 51(2), 183-202.

Mitchell, T. R. (1982). Motivation: New direction for theory, research, and practice. The Academy of Management Review, 1(81), 80-88.

Mobley, W., Horner, S., \& Hollingsworth, A. (1978). An evaluation of the precursors of hospital employee turnover. Journal of Applied Psychology, 4(63), 408-414.

Mudie, P. M. (1987). Internal marketing: cause for concern. Quarterly Review of Marketing, $12(3 / 4), 21-4$

Mumby, D. K. (2013). Organizational Communication: A Critical Approach. USA: Sage Publications.

Narteh, B., \& Odoom, R. (2015). Does internal marketing influence employee loyalty? Evidence from the Ghanaian banking industry. Services Marketing Quarterly, (36)2, 112-135.

Novianty R.R, and Evita S.N (2018) Financial Incentives: The Impact on Employee Motivation Academy of Strategic Management Journal, 17(6), 6-297.

Nunnally, J.C. (1978). Psychometric Theory. 2nd Edition, McGraw-Hill, New York.

Omar, K, \& Shehada, M. (2015). The impact of internal marketing on retaining employees at private hospitals in Amman, Jordan. International Journal of Management and Commerce Innovations, (2)2, 606-619.

Ongori, H. (2007). A review of the literature on employee turnover. African Journal of Business Management, (1)3, 49-54.

Pallant, J. (2010). SPSS survival manual: A step by step guide to data analysis using SPSS. England: Mcgraw-Hill.

Piercy, N., \& Morgan, N. (1991). Internal marketing - the missing half of the marketing programme. Long-range planning, 24(2), 82-93.

Pinder, C. (2008). Work motivation in organizational behaviour (2nd edition Ed.).New York: Psychology Press. 
Ramlall, S. (2004). A review of employee motivation theories and their implications for employee retention within organizations. The Journal of American Academy of Business, (5)1/2. 52-63.

Reid, R. D., \& Bojanic, C. D. (2010). Hospitality Marketing. Hoboken: NJ, John Willey \& Sons.

Robbins, S. (1993). Organizational Behavior. Englewood Cliffs, NJ: Prentice-Hall.

Safiullah, A. B. (2014). Impact of rewards on employee motivation of the telecommunication industry of Bangladesh: An empirical study. Journal of Business and Management, 16(12), 22-30.

Samuel, M. O., \& Chipunza, C. (2009). Employee retention and turnover: Using motivational variables as a panacea. African Journal of Business Management, 3(9), 410-415.

Sandhya, K., \& Kumar, D. P. (2011) Employee retention by motivation. Indian Journal of Science and Technology, 12 (4), 1778-1782.

Sarmad, Dr. (2016). Motivation and compensation as predictors of employees' Retention. Evidence from Public Sector Oil and Gas Selling Organizations. Journal of Behavioral Sciences, 26,174-188.

Sekaran, U., \& Bougie, R. (2010). Research Methods for Business: A Skill Building Approach. Chichester, West Sussex, UK: John Wiley \& Sons.

Shah, M., \& Asad, M. (2018). Effect of motivation on employee retention: Mediating role of perceived organizational support. European Online Journal of Natural and Social Sciences, 7(2), 511-520.

Tag-Eldeen, A., \& El-Said, O.A. (2011). Implementation of internal marketing on a sample of Egyptian five-star hotels. Anatolia, an International Journal of Tourism and Hospitality Research, 2(22), 153-167.

Talent: A focus group study. Industrial Management \& Data Systems, (99)6, 251-256.

Titus, N., \& Adiza, G.R. (2018). Motivation: A Panacea for Employees Performance and Retention. International Journal of Science and Research (IJSR), 8(1), 931-936.

Turkoz, I., \& Akyol, A. (2008). Internal marketing and hotel performance. Anatolia, an International Journal of Tourism and Hospitality Research, (19)1, 149-177.

Waddah I., \& Nooraini, M. S. (2015). Validation of measurement model of internal marketing in the banking sector in Yemen. International Academic Research Journal of Social Science, 2(1), 131-138.

Wilson A., Zeithaml V. A., Bitner M. J., \& Gremler D. D. (2008). Services Marketing: Integrating Customer Focus across the Firm. Dubuque, IA: McGraw-Hill Education.

Yamane, T. (1973). An Introduction Analysis. 3rd Edition, Harper and Row, New York.

Zahra, A. I., \& Hummayoun, N. (2014) Employee training and its effect on employees' job motivation and commitment: developing and proposing a conceptual model. IOSR Journal of Business and Management (IOSR-JBM), 16(9), 60-68.

\section{Author Biography}

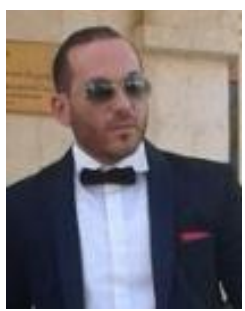

Romeo Abou Melhem is currently a Doctorate of Business

Administration student at Cyprus International University. 


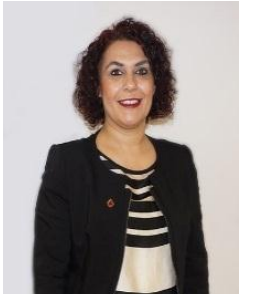

Hale Ozgit is currently an associate professor at the School of Tourism and Hotel Management at Cyprus International University, School of Tourism and Hotel Management. Her PhD focused on the evaluation of tourism education in higher education from the strategic management perspective. Her research interests are tourism, tourism education, organizational behavior, and human resources management. 